\title{
Antidiabetic and Antioxidant Effect Combination Vasconcellea pubescens A.DC. and Momordica charantia L. Extract in Alloxan- Induced Diabetic Rats
}

\author{
Heru Sasongko ${ }^{1 *}$, Ratih Guswinda Lestari ${ }^{1}$, Adi Yugatama ${ }^{1}$, Yeni Farida' ${ }^{1}$, Sugiyarto ${ }^{2}$
}

Heru Sasongko ${ }^{1, *}$, Ratih

Guswinda Lestari ${ }^{1}$, Adi

Yugatama', Yeni Farida',

Sugiyarto ${ }^{2}$

'Department of Pharmacy, Universitas Sebelas Maret, Jl. Ir. Sutami No. 36 A, Surakarta 57126, INDONESIA.

${ }^{2}$ Department of Biology, Universitas Sebelas

Maret, JI. Ir. Sutami No. 36 A, Surakarto

57126, INDONESIA.

\section{Correspondence}

Heru Sasongko

Department of Pharmacy, Universitas Sebelas Maret, JI. Ir. Sutami No. 36 A Surakarta 57126, INDONESIA.

E-mail: heru_sasongko@staff.uns.ac.id

History

- Submission Date: 12-12-2019;

- Review completed: 24-12-2019.

- Accepted Date: 19-01-2020.

DOI : $10.5530 /$ pj.2020.12.49

Article Available online

http://www.phcogj.com/v12/i2

\section{Copyright}

(C) 2020 Phcogj.Com. This is an open access article distributed under the terms of the Creative Commons Attribution 4.0 International license.

\begin{abstract}
Introduction: Mountain papaya (Vasconcellea pubescens A.DC.) and bitter melon (Momordica charantia L.) fruit extract have total flavonoids and some metabolite from its contains. The use of a single dose in the treatment of diabetes is often considered to lack a strong effect. Giving a combination of the compound is a solution to provide a synergistic effect in treatment. Material and Methods: Rat were divided into eight groups (normal, negative control, glibenclamide as a positive control, and five dose extract group). The single dose mountain papaya extract (MPE) and bitter melon extract (BME) were given at $174 \mathrm{mg} / \mathrm{kg}$ b.w of MPE, and $380 \mathrm{mg} / \mathrm{kg} \mathrm{b.w} \mathrm{of}$ BME in oral administration. Combination of MPE:BME (25:75, 50:50, 75:25)\% or (87:190; $44: 285$ and $130: 95) \mathrm{mg} / \mathrm{kg}$ b.w in oral administration. Induction of diabetes used alloxan dose of $150 \mathrm{mg} / \mathrm{kg}$ b.w intraperitoneally. The treatment was performed for 21 days with a frequency of once a day. Blood sugar level was measured at pretest, $7^{\text {th }}, 14^{\text {th }}$, and $21^{\text {st }}$ days. At the end of the test, measurements of malondialdehyde (MDA), glutathione (GSH), and pancreatic morphology were measured. Data were analyzed by ANOVA statistic. Results: The single and combination of MPE-BME showed an decrease in blood glucose levels significantly compared with the negative control ( $p \leq 0.05$ ). The same results from measurements of levels of malondialdehyde (MDA), glutathione (GSH), and pancreatic morphology. Conclusions: Based on the research, a combination of the MPE-BME had antidiabetic and antioxidant activity, but the activity was not significantly different from both single-dose extract ( $p>0.05$ ).
\end{abstract}

Key words: Antidiabetic, Antioxidant, Flavonoids, Momordica, Synergistic, Vasconcellea.

\section{INTRODUCTION}

Diabetes mellitus (DM) is a metabolic disorder that occurs because the pancreas cannot produce insulin or the body is unable to use insulin produced effectively. ${ }^{1,2}$ Indonesia estimates the $6^{\text {th }}$ rank after China, India, the United States, Brazil and Mexico with 10.3 million sufferers. The use of oral antidiabetic drugs that are long enough for a patient's lifetime is done only for them. Many studies have been conducted related to the use of oral antidiabetic drugs. ${ }^{3-5}$ Therefore, many people choose to use traditional medicine that is accepted to be safer, affordable, and effective. ${ }^{6,7}$

Mountain papaya (Vasconcellea pubescens A.DC.) and bitter melon fruit (Momordica charantia L.) are several types of plants that are commonly found in Indonesia. Mountain papaya contains flavonoids, alkaloids, polyphenols, cysteine proteases, and papain which are antidiabetic agents. ${ }^{89}$ Total flavonoids contained in mountain papaya fruit have been permitted as antidiabetic by preventing $\beta$ cell damage, insulin, and insulin signaling and inhibiting $\alpha$-glucosidase., ${ }^{9,10}$ Bitter melon fruit contains flavonoids, alkaloids, saponins, polysaccharides, proteins, triterpenoids, quinine, and amino acids. ${ }^{11}$ Fruit extracts can increase insulin secretion and protect the pancreas, inhibit $\alpha$-glucosidase and inhibit $\alpha$-amylase. ${ }^{12-14}$
Innovations in oral antidiabetic agents from natural ingredients have been developed. The use of a single dose in the treatment of diabetes is often considered to lack a strong effect. Giving a combination of ingredients is a solution to provide a synergistic effect in a treatment. In this study, we tested the antidiabetic activity of a combination of ethanol extract of mountain papaya and bitter melon fruit.

\section{MATERIALS AND METHODS}

\section{Materials}

Wistar rats were obtained from Faculty of medicine, Universitas Sebelas Maret, Surakarta, Indonesia. Standard quercetin (SigmaAldrich ${ }^{\circledR}$ ), alloxan monohydrate $\left(\right.$ Aldrich $\left.^{\circledR}\right)$, reagent of lipid peroxidation and glutation colorimetric, aluminum chloride colorimetric reagent, glucose oxidasephenom aminoantipyrine (GOD-PAP) from Biosystem, hematoxylin and eosin.

\section{Extraction and analysis of total flavonoids}

Mountain papaya and bitter melon extracted separately using the maceration method with ethanol $70 \%$ solvent. The test material obtained is washed and separated from the seeds, cut into small pieces and dried with a $40^{\circ} \mathrm{C}$ oven. Dry simplisia is macerated for $3 \times 24$ hours. The filtrate was evaporated with a rotary evaporator at $50^{\circ} \mathrm{C}$ until a thick extract was obtained. ${ }^{15}$ The method used is the aluminum

Cite this article: Sasongko H, Lestari RG, Yugatama A, Farida Y, Sugiyarto. Antidiabetic and Antioxidant Effect Combination Vasconcellea pubescens A.DC. and Momordica charantia L. Extract in Alloxan-Induced Diabetic Rats. Pharmacog J. 2020;12(2):311-5. 
chloride colorimetric method using a UV-Vis spectrophotometer at $\lambda=439 \mathrm{~nm}$. The standard used is Quercetin concentration series 6.125, $12.5,25,50$, and 100 ppm. ${ }^{16}$

\section{In vivo experiment}

The animal handling was approved from the health research ethics committee of Faculty of Medicine of Universitas Sebelas Maret No. 1046/III/HREC/2019. The rats were acclimatized for 7 days, then measured blood sugar levels pretest. Animal diabetes was done by inducing with alloxan monohydrate dose $150 \mathrm{mg} / \mathrm{kg}$ body weight (b.w) intraperitonially (i.p). ${ }^{17}$ After 72 hours rats were treated with intensity one time a day. Animal experiments were divided into 8 groups: normal (I), positive control (II), negative control (III), and 5 test groups. Glibenclamide $0.45 \mathrm{mg} / \mathrm{kg}$ b.w was used as positive control. Test groups consist of combination MPE-BME extract 50\%:50\% (IV), 25\%:75\% (V), 75\%:25\% (VI), MPE 100\% (VII), and BME 100\% (VIII). The dose of MPE $100 \%$ was $173 \mathrm{mg} / \mathrm{kg}$ b.w and the dose of BME was $100 \% 380 \mathrm{mg} / \mathrm{kg}$ b.w. The extract dose was based on the total flavonoid value of each extract. ${ }^{18}$ On the $21^{\text {st }}$ day euthanasia was performed with cervical dislocation, then pancreatic and hepatic organ harvesting was carried out.

\section{Blood glucose level}

Blood glucose measurements were made before alloxan induced (pretest), the day- $7^{\text {th }}, 14^{\text {th }}$, and $21^{\text {th }}$. Blood glucose measurement using GOD-PAP method with the Biochemisty Analizer by Biosystem instrument $\lambda=500 \mathrm{~nm}$.

\section{Rat liver homogenate}

Taken $500 \mathrm{mg}$ of liver added in $5 \mathrm{~mL}$ of a solution of $0.15 \mathrm{M}$ tris- $\mathrm{HCl}$ ( $\mathrm{pH}$ 7.4) then shaken to homogenize it to obtain a homogenate of $10 \%$ $\mathrm{b} / \mathrm{v} .{ }^{19}$

\section{Malondialdehyde (MDA) measurement}

Plasma malondialdehyde measurement was done using the thiobarbituric acid reactive substances (TBARS) method with a UVVis spectrophotometer. $0.2 \mathrm{~mL}$ liver homogenate, plus $0.2 \mathrm{~mL}$ sodium decocyl sulfate (SDS) $8.1 \%, 1.5 \mathrm{~mL}$ of acetic acid $20 \%, 1.5 \mathrm{~mL}$ of TBA $0.8 \%$, and aquadest and heated at $95^{\circ} \mathrm{C}$ for 60 minutes, then added 4 $\mathrm{mL}$ of $10 \% \mathrm{TCA}$, centrifuged at $3000 \mathrm{rpm}$ for 10 minutes. After that the absorption is read at a wavelength of $532 \mathrm{~nm} \cdot .^{20,21}$

\section{Glutathione (GSH) measurement}

Glutation level measurement refers to the method developed by Ellman et al., (1984), liver homogenate $(0.75 \mathrm{~mL})$ was added with $0.75 \mathrm{~mL}$ of $10 \%$ TCA, centrifuged at $200 \mathrm{rpm}$ for 10 minutes, added with $1.8 \mathrm{~mL}$ ellman reagent $(5,5$ '-dithio bis-2-nitrobenzoic acid), absorbance was measured by UV-Vis spectrophotometer $\lambda=412 \mathrm{~nm}^{22}$

\section{Histological study}

Pancreatic histology testing aims to look at the general morphology of the pancreas. Fixation of pancreatic organs using 10\% NBF solution. Tissue preparation of pancreas was colored with Hematoxylin-Eosin (HE). Hematoxylin would give a blue color on the nucleus and eosin gave a red color on cytoplasm and extracellular matrix..$^{23}$ Histological examination carried out qualitatively to see the general morphology of pancreatic cells by counting the number of normal pancreatic cells and pancreatic cells undergoing necrosis in the form of nuclear shrinkage (pyknosis), nucleus rupture (cariorrexis), and disappearance of nucleus (karyolysis) on the Langerhans Island. ${ }^{8}$

\section{Statistical analysis}

The analysis of blood sugar, GSH, and MDA levels was performed using statistics, while analysis of pancreatic histological data was carried out descriptively by looking at the general morphology of pancreatic cells. Statistical analysis was preceded by a normality test with Shapiro Wilk and a homogeneity test with the Levene's Test. Parametric tests were carried out with One Way ANOVA, post hoc LSD.

\section{RESULTS}

\section{Total flavonoid analysis}

The total flavonoid (quercetin equivalent) of MPE was $121.334 \pm 3.404$ $\mathrm{mg} / 100 \mathrm{~g}$ ethanol extract, while the total flavonoid of BME was 55.795 $\pm 1.601 \mathrm{mg} / 100 \mathrm{~g}$ ethanol extract.

\section{Blood glucose analysis}

On the day $21^{\text {th }}$, after treatment there was significant normalization and homogenization of fasting blood glucose every weeks, observed in diabetic experimental animals treated with combination MPE and BME. The standard as positive controls is glibenclamide $0.45 \mathrm{mg} / \mathrm{kg}$ b.w. Glibenclamid administer gave decrease fasting blood glucose that had $p>0.05$ from negative controls. MPE and BME have antidiabetic activities because they have significantly different sugar levels with negative controls. The antidiabetic activity of MPE and BME is almost the same $(p>0.05)$ with glibenclamide. On the day $7^{\text {th }}$ the blood sugar levels of mice increased by 126.661-201.197 mg/dL. Blood sugar levels of rats after alloxan induction ranged from $200-260 \mathrm{mg} / \mathrm{dL}$ can be said to experience hyperglycemia. ${ }^{24}$ Blood sugar levels on the day $7^{\text {th }}$ of all extract treatment groups differed significantly from the negative group, but groups IV and VI did not differ significantly from positive controls. On the $14^{\text {th }}$ and $21^{\text {st }}$ days the blood sugar levels of the treatment group extract (IV-VIII) both combination and single were significantly different from negative control, but not significantly different from positive control (Figure 1)

\section{Histological analysis}

The treatment extract group that had the lowest total cell damage was group IV namely the test animals that were given CFE and BFE (50:50). This is thought to occur because the combination of a 50:50 MPE and BME ratio may has a synergistic effect in improving pancreatic morphology. The presence of flavonoid content in MPE and BME has antioxidant properties that are able to ward off free radicals causing pancreatic cell damage and inhibit pancreatic cell damage so that the extract treatment group has higher normal cell counts compared to negative controls.

\section{Gluthatione (GSH)}

The results of normality and homogeneity tests showed that all groups in this study had normal and homogeneous data distribution with $\mathrm{p}$ values $>0.05$ (Table 1). ANOVA results showed a significant difference

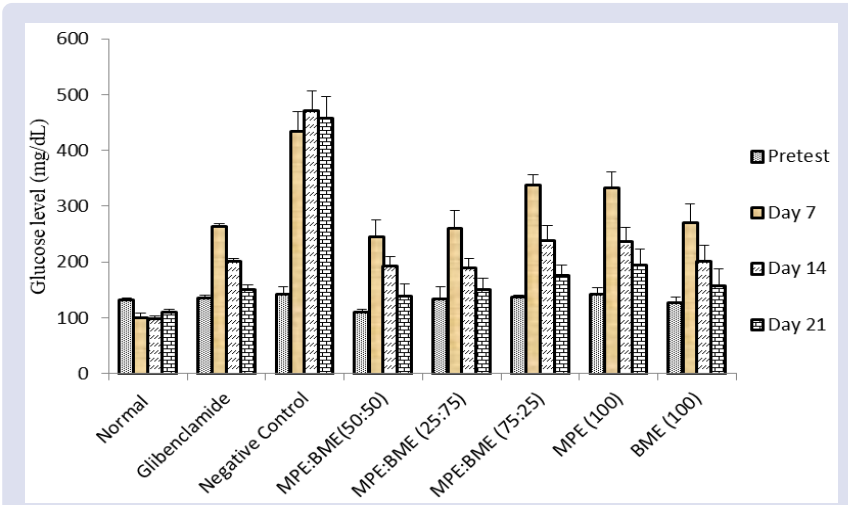

Figure 1: Effect of combination ethanol extract (MPE-BME) on blood glucose of rats. 
between the negative group with the CFE and BFE groups $(p<0.01)$. The lowest GSH levels are the negative control group induced by alloxan, because alloxan can cause the failure of endogenous antioxidant defense mechanisms in counteracting free radicals. The lower the level of GSH, the higher the damage to the liver. GSH in the positive control group $31.8778 \pm 1.8558 \mu \mathrm{M} / \mathrm{g}$ of the liver showed that glibenclamide can suppress the hepatotoxic activity of alloxan. Groups IV, VII, and VIII had GSH values that were not significantly different from positive control ( $p>0.01)$. The GSH value of the treatment group combination extract was not significantly different from the single extract treatment group (Figure 2).

\section{Malondialdehyde (MDA)}

The highest MDA level is known in the negative control group induced by alloxan. While the drug control group (glibenclamide) has the lowest MDA levels (Table 1). High levels of MDA indicate cellular damage due to free radicals. ${ }^{29}$ All extract groups (IV-VIII) were significantly different $(p<0.01)$ from negative control, but only groups IV and VIII were not significantly different from positive controls $(p>0.01)$. This shows that the combination of MPE-BME (50:50) and BME (100) has almost the same activity as glibenclamide because MPE and BME contain flavonoids which act as strong antioxidants compared to vitamin $\mathrm{C}$ and vitamin $\mathrm{E}^{30}$ The MDA value of the MPE group (VII) was not significantly different $(p>0.01)$ from the BME group (VIII) and the MDA value of the combination group (IV-VI) was not significantly different $(p>0.01)$ from the MPE and BME groups (VII and VIII) .

\section{DISCUSSION}

The antidiabetic activity of BME is higher than that of MPE because its fruit containing $\mathrm{p}$-insulin polypeptide which works like insulin and charantin which can increase glucose in liver cells and muscles, ${ }^{12,25}$ has a component that works similar to sulfonylurea. ${ }^{26}$ Histology results of normal cell pancreas are shown with a rounded cell shape with a clear nucleus, uniform cell shape, and do not experience edema. ${ }^{27}$ The pancreatic tissue of the negative control group has more necrosis cells than the treatment of both single and combination MPE and BME extracts, which indicates more severe damage due to alloxan induction. Cells that experience pyknosis are essentially wrinkled and basophils, dark in irregular boundaries. The cell nucleus that undergoes carioerexis will fragment or disintegrate by leaving fragments of chromatin substances scattered within the cell. In the nucleic cell undergoing karyolysis, chromatin basophils turn pale, the cell nucleus loses the ability to be stained and simply disappear. This condition is severe damage and irreversible even with cell regeneration activity. ${ }^{8}$

Measurement of GSH levels is done by referring to the Ellman method. In principle, ditio bisnitro benzoate (DTNB) will react with GSH to produce a yellow tionitro benzoate compound. ${ }^{22}$ Malondialdehyde is a metabolite that results from lipid peroxidation by free radicals. ${ }^{28}$ The principle of the TBARS method is that MDA will form a complex with pink TBA in an acidic atmosphere. ${ }^{15}$ The highest MDA level is known in the negative control group induced by alloxan. While the drug control group (glibenclamide) has the lowest MDA levels.

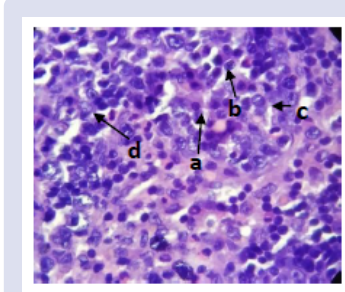

I

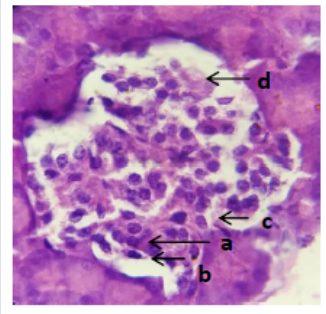

V

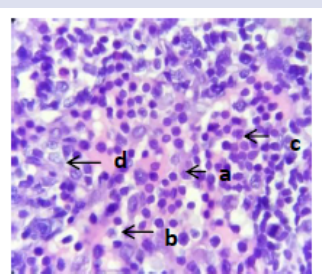

II

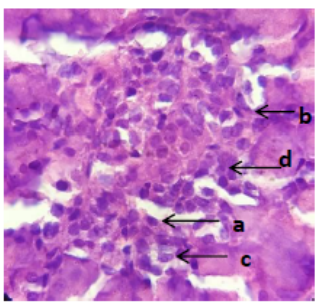

VI

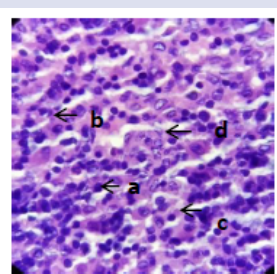

III

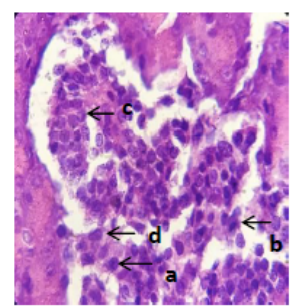

VII

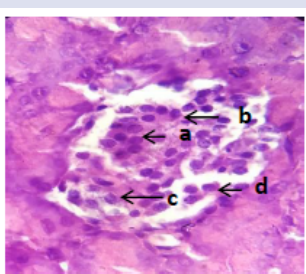

IV

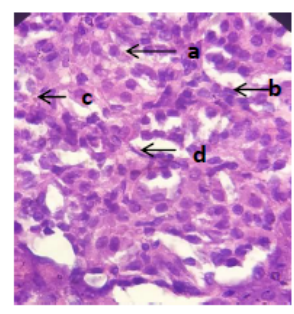

VIII

Figure 2: Histology of pancreas with HE staining. (II)Positive control group (III) Negative control group (IV) MPE-BME (50:50) (V) MPE-BME (25:75) (VI) MPE-BME (75:25) (VII) MPE (100) (VIII) BME (100); (a) normal cell (b) pyknosis cell (c) cariorrexis cell (d) karyolysis cell.

Table 1: Antioxidant activity of MPE-BME with the GSH and MDA parameters.

\begin{tabular}{cccc}
\hline Groups & & $\begin{array}{c}\text { Mean GSH level } \\
(\mu \mathrm{M} / \mathrm{g} \text { Hepar } \pm \text { SEM) }\end{array}$ & $\begin{array}{c}\text { Mean MDA level } \\
(\mu \mathrm{M} / \mathrm{g} \mathrm{Hepar} \pm \text { SEM) }\end{array}$ \\
\hline I & Normal & $31.6036 \pm 2.6248^{\mathrm{ab}}$ & $0.0359 \pm 0.0054^{\mathrm{ab}^{*}}$ \\
II & Glibenclamide & $31.8778 \pm 2.9558^{\mathrm{ab}^{* \sharp}}$ & $0.0260 \pm 0.0057^{\mathrm{ab}^{*}}$ \\
III & Negative Control & $13.8151 \pm 1.8581^{\mathrm{c}^{*}}$ & $0.1064 \pm 0.0094^{\mathrm{c}^{*}}$ \\
IV & MPE:BME(50:50) & $30.1434 \pm 1.7470^{\mathrm{ab}}$ & $0.0503 \pm 0.0032^{\mathrm{ab}}$ \\
V & MPE:BME (25:75) & $23.8242 \pm 1.6836^{\mathrm{abc}}$ & $0.0697 \pm 0.0107^{\mathrm{abc}}$ \\
VI & MPE:BME (75:25) & $22.5729 \pm 1.5534^{\mathrm{abc}}$ & $0.0591 \pm 0.0075^{\mathrm{ac}}$ \\
VII & MPE (100) & $26.2291 \pm 2.0982^{\mathrm{ab}}$ & $0.0759 \pm 0.0099^{\mathrm{abc}}$ \\
VIII & BME (100) & $26.2304 \pm 1.1320^{\mathrm{ab}}$ & $0.0467 \pm 0.0087^{\mathrm{ab}}$ \\
\hline
\end{tabular}

(a) Significantly different from negative control $p<0.05$ (b) significantly different from negative control $p<0.01$ (c) significantly different from positive control $p<0.01\left(^{*}\right)$ significantly different from VII group $(p<0.01)$ (\#) significantly different from VIII group $(p<0.01)$ 


\section{CONCLUSION}

The single of MPE at dose $173 \mathrm{mg} / \mathrm{kg}$ b.w, BME at dose $380 \mathrm{mg} / \mathrm{kg}$ b.w, and combination of both (50:50, 25:75, and 75:25) have an antidiabetic and antioxidant effect. The combination of MPE and BME has the same effective antidiabetic activity as glibenclamide. Antidiabetic and antioxidant activity of the combination extract did not differ significantly from the single extract.

\section{CONFLICTS OF INTEREST}

The authors declared no conflicts of interest

\section{ACKNOWLEDGMENTS}

All authors say to thank for Universitas Sebelas Maret for the PNBP 2019 funding by Hibah Fundamental scheme.

\section{REFERENCES}

1. Association AD. Diagnosis and Classification of Diabetes Mellitus. Diabetes Care. 2010;33(Supplement 1):S62-9

2. Kovatchev B. A Century of Diabetes Technology: Signals, Models, and Artificial Pancreas Control. Trends Endocrinol Metab. 2019;30(7):432-44.

3. Fasanella DR, Luttrell SE, Tejada FR, Ngokobi H, Ayuk-Tabe M. Chapter 43 - Use of Antidiabetic, Antihypertensive, and Psychotropic Drugs in Pregnancy. In: Ray SD, editor. Side Effects of Drugs Annual. Elsevier; 2018;547-58.

4. Ghadge AA, Harke SM, Khadke SP, Diwan AG, Pankaj M, Kulkarni OP, et al. Circulatory adipocytokines and lipid profile variations in type-2 diabetic subjects: Desirable side-effects of antidiabetic drugs. Diabetes Metab Syndr Clin Res Rev. 2014;8(4):230-2

5. Khalili H, Derakhshan N, Niakan A, Ghaffarpasand F, Salehi M, Eshraghian H, et al. Effects of Oral Glibenclamide on Brain Contusion Volume and Functional Outcome of Patients with Moderate and Severe Traumatic Brain Injuries: A Randomized Double-Blind Placebo-Controlled Clinical Trial. World Neurosurg. 2017;101:130-6.

6. Jiménez-Martín PJ, Liu H. Exploring the health advantages and disadvantages of static and dynamic postures of Qigong and its use as a Traditional and Complementary Medicine. Eur J Integr Med. 2018;24:61-4.

7. Kalaitzopoulos D. The potential of Precision Medicine. New Horiz Transl Med. 2016;3(2):63-5

8. Sasongko H, Pratiwi D, Amartiwi T, Efendi NR, Sugiyarto. Hepatoprotective Effect of Mountain Papaya (Vasconcellea pubescens A.DC.) Fruit Extract against Acetaminophen-Induced Acute Liver Damage. In 2019;66-70.

9. Vega-Gálvez A, Poblete J, Quispe-Fuentes I, Uribe E, Bilbao-Sainz C, Pastén A. Chemical and bioactive characterization of papaya (Vasconcellea pubescens) under different drying technologies: evaluation of antioxidant and antidiabetic potential. J Food Meas Charact. 2019;27.

10. Babu PVA, Liu D, Gilbert ER. Recent advances in understanding the antidiabetic actions of dietary flavonoids. J Nutr Biochem. 2013;24(11):1777-89.

11. Chen F, Huang G, Yang Z, Hou Y. Antioxidant activity of Momordica charantia polysaccharide and its derivatives. Int J Biol Macromol. 2019;22.

12. Bai $W$, Zhang $C$, Chen $H$. Transcriptomic analysis of Momordica charantia polysaccharide on streptozotocin-induced diabetic rats. Gene. 2018;675:20816.
13. Gao Z, Ngo C, Ye W, Rodriguez JD, Keire D, Sun D, et al. Effects of Dissolution Medium $\mathrm{pH}$ and Simulated Gastrointestinal Contraction on Drug Release From Nifedipine Extended-Release Tablets* . J Pharm Sci. 2019;108(3):1189-94.

14. Wang Q, Wu X, Shi F, Liu Y. Comparison of antidiabetic effects of saponins and polysaccharides from Momordica charantia L. in STZ-induced type 2 diabetic mice. Biomed Pharmacother. 2019;109:744-50.

15. Sasongko H, Efendi NR, Sugiyarto. The ethanolic extract of mountain papaya (Vasconcellea pubescens A.DC.) fruit against lipid peroxidation of rat liver tissues. AIP Conf Proc. 2018:2019(1):50001.

16. Chang $\mathrm{C}-\mathrm{C}$, Yang $\mathrm{M}-\mathrm{H}$, Wen $\mathrm{H}-\mathrm{M}$, Chern J-C. Estimation of total flavonoid content in propolis by two complementary colorimetric methods. J Food Drug Anal. 2002;10(3)

17. Anyanwu GO, Iqbal J, Khan SU, Zaib S, Rauf K, Onyeneke CE, et al. Antidiabetic activities of chloroform fraction of Anthocleista vogelii Planch root bark in rats with diet- and alloxan-induced obesity-diabetes. J Ethnopharmacol. 2019;229:293-302.

18. Mourya P, Shukla A, Rai G, Lodhi S. Hypoglycemic and hypolipidemic effects of ethanolic and aqueous extracts from Ziziphus oenoplia (L) Mill on alloxaninduced diabetic rats. Beni-Suef Univ J Basic Appl Sci. 2017;6(1):1-9.

19. Nurrochmad A, Margono SA, Sardjiman, Hakim AR, Ernawati, Kurniawati E, et al. Hepatoprotective and antioxidant activity of pentagamavunon-0 against carbon tetrachloride-induced hepatic injury in rats. Asian Pac J Trop Med. 2013;6(6):438-42

20. Deeseenthum S, Luang-In V, John S, Chottanom P, Chunchom S, Chunchom S. Effects of Kefir Fermentation on Antioxidation Activities (in vitro) and Antioxidative Stress (in vivo) of Three Thai Rice Milk Varieties Prepared by Ultrasonication Technique. Pharmacogn J. 2018:10(5):1061-6.

21. Taepongsorat $L$, Phadungkit $M$, Phadungkit $M$, Phadungkit $M$. Effects of Asparagus racemosus Root Extracts on Serum Lipid Profiles, Lipid Peroxidation and Superoxide Dismutase in Ovariectomized Rat. Pharmacogn J. 2018;10(5):1036-41.

22. Pal A, Kumar K, Bhushan B, Saharan V. Ashwagandha Root Extract Inhibits Acetylcholine Esterase, Protein Modification and Ameliorates;-Induced Oxidative Stress in Rat Lymphocytes. Pharmacogn J. 2017;9(3):302-9.

23. Kanakia S, Toussaint JD, Mullick Chowdhury S, Tembulkar T, Lee S, Jiang Y-P, et al. Dose ranging, expanded acute toxicity and safety pharmacology studies for intravenously administered functionalized graphene nanoparticle formulations. Biomaterials. 2014:35(25):7022-31.

24. Pari L, Uma Maheswari J. Hypoglycaemic effect of Musa sapientum L. in alloxan-induced diabetic rats. J Ethnopharmacol. 1999;68(1):321-5.

25. Gao H, Wen J-J, Hu J-L, Nie Q-X, Chen $\mathrm{H}-\mathrm{H}$, Xiong $\mathrm{T}$, et al. Fermented Momordica charantia L. juice modulates hyperglycemia, lipid profile, and gut microbiota in type 2 diabetic rats. Food Res Int. 2019;121:367-78.

26. Rotshteyn Y, Zito SW. Application of modified in vitro screening procedure for identifying herbals possessing sulfonylurea-like activity. J Ethnopharmacol. 2004;93(2):337-44

27. Solcia E, Klöppel G, Sobin LH. Histological Typing of Endocrine Tumours Springer Science \& Business Media; 2012;186.

28. Yagi K. Lipid Peroxides and Related Radicals in Clinical Medicine. In: Free Radicals in Diagnostic Medicine. Springer, Boston, MA; 1994;1-15.

29. Prasanna B, Anand A, Anand A, Anand A. Cinnamon species: In vivo AntiOxidant Activity of Ethanolic Extracts of Cinnamon Zeylanicum and Cinnamon Cassicae Barks. Pharmacogn J. 2019;11(2):245-7.

30. Sarker U, Oba S. Response of nutrients, minerals, antioxidant leaf pigments, vitamins, polyphenol, flavonoid and antioxidant activity in selected vegetable amaranth under four soil water content. Food Chem. 2018;252:72-83. 


\section{GRAPHICAL ABSTRACT}

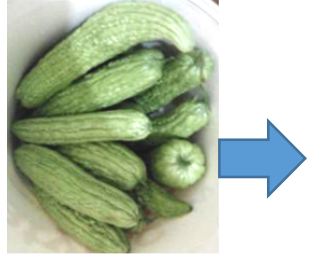

Bitter melon (BM)

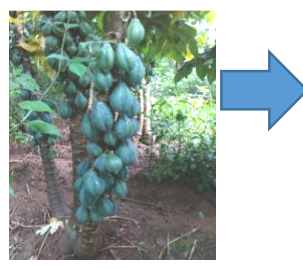

Mountain papaya (MP)

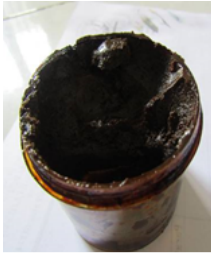

Bitter melon extract (BME)

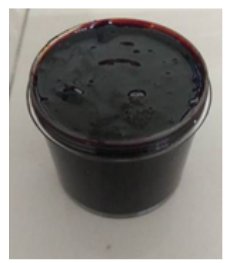

Mountain papaya extract (MPL)

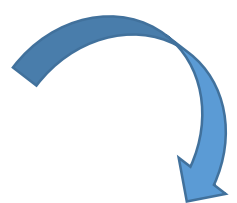

The single and combination of MPEBME showed an decrease in blood glucose levels significantly

Levels of malondialdehyde (MDA), glutathione $(\mathrm{GSH})$, and pancreatic morphology were equal in single and combination groups.

\section{ABOUT AUTHORS}

- Heru Sasongko, M.Sc.,Apt: Worked as a lecturer and researcher at department pharmacy Universitas Sebelas Maret, Surakarta Indonesia. He has research mainly focused on "pharmacology activity from medicinal plants". He has published 7 papers in journals and proceedings on Scopus indexing.

- Ratih Guswinda Lestari, S.Farm: Bachelor student at department pharmacy Universitas Sebelas Maret, Surakarta Indonesia.

- Adi Yugatama, M.Sc.,Apt: Worked as a lecturer and researcher at department pharmacy Universitas Sebelas Maret, Surakarta Indonesia. He has research mainly focused on pharmaceutical analysis. He has published 9 papers in journals and proceedings on Scopus indexing.

- Yeni Farida, M.Sc.,Apt: Worked as a lecturer and researcher at department pharmacy Universitas Sebelas Maret, Surakarta Indonesia. He has research mainly focused on clinical pharmacy, pharmacoeconomics, and pharmacoepidemiology. He has published 3 papers in journals and proceedings on Scopus indexing.

- Prof Sugiyarto: Professor in department biology Universitas Sebelas Maret, Surakarta Indonesia. He has research mainly focused on ecology and biodiversity. He has published 20 papers in journals and proceedings on Scopus indexing.

Cite this article: Sasongko H, Lestari RG, Yugatama A, Farida Y, Sugiyarto. Antidiabetic and Antioxidant Effect Combination Vasconcellea pubescens A.DC. and Momordica charantia L. Extract in Alloxan-Induced Diabetic Rats. Pharmacog J. 2020;12(2):3115. 